\title{
Helicobacter in Biliary Calculus Disease: Histopathological and Serological Association in a Rural Population of Southern India
}

\author{
Sreeramulu PN, Harish Kumar, Karthik Hareen TVK*, Srinivasan D and Prajeeth Reddy \\ Department of General Surgery, Sri DevrajUrs Medical College, India
}

Submission: March 23, 2017; Published: March 27, 2017

*Corresponding author: Karthik Hareen TVK, Department of General Surgery, Sri DevrajUrs Medical College, Kolar, India, Tel: 9538840441; Email: karthikhareen08@gmail.com

\begin{abstract}
Introduction: Biliary calculus disease is one of the most common disorders and is an important cause of morbidity world over. In USA and Europe, the prevalence of biliary calculus disease ranges from $7 \%$ to $33 \%$ among general population. Though accurate estimates are not available, gall stones disease forms an important cause of suffering in India. In recent years, Helicobacter pylori has been detected in the human bile and gall bladder tissues. This has evoked considerable interest in the possibilities of colonization and causation of biliary calculus disease by this organism.Here is the study for investigating the evidence of Helicobacter infection by histopathological and serological methods at R.L. Jalappa hospital, Kolar, Karnataka which caters mainly for rural population.
\end{abstract}

Materials and methods: During the period November 2011 to August 2013, 65 patients with clinical features of biliary calculus disease admitted at R.L.Jalappa hospital, Kolar were included in the study. After performing cholecystectomy on the patients selected as above, gall bladder tissues were fixed in $10 \%$ formaldehyde and were subjected to histopathological examination. Patients who were treated for Helicobacter pylori infections in the past 4 weeks and those with clinical features of gastritis were excluded from the study. A $5 \mathrm{ml}$ blood sample was collected prior to surgery from all the above patients, serum was separated and tested for IgM antibodies to Helicobacter pylori using a commercially available ELISA kit.

Results: Sixty five patients of calculus cholecystitis were included in the study. Among them, 27(41.5\%) were males and 38 (58.5\%) were females. The mean age of overall study population was $41.78 \pm 8.8$ years. The youngest patient was 14 years old and the oldest patient was 77 years old. Among the patients studied, all patients had pain in the right hypochondrium, in addition, $20(30.7 \%)$ had dyspepsia and $9(13.8 \%)$ had fever. There were no patients with jaundice or mass per abdomen

Conclusion: In the study reported here from southern India, we found that Helicobacter species in gall bladder tissue could be detected in $3(4.6 \%)$ of 65 patients with Biliary calculus disease. These findings suggest that Helicobacter pylori infection in biliary calculus disease is less common among the rural population from southern India. IgM antibody against Helicobacter pylori could act as a serological marker for associating Helicobacter species with biliary calculus disease.

Keywords: Helicobacter pylori; Biliary Calculus Disease; Rural setup

\section{Introduction}

Biliary calculus disease is one of the most common disorders and is an important cause of morbidity world over. In USA and Europe, the prevalence of biliary calculus disease ranges from $7 \%$ to $33 \%$ among general population. Though accurate estimates are not available, gall stones disease forms an important cause of suffering in India. It is thought to be more common in northern than the southern parts of the country [1-3]. In recent years, Helicobacter pylori has been detected in the human bile and gall bladder tissues. This has evoked considerable interest in the possibilities of colonization and causation of biliary calculus disease by this organism [4]. In addition to Helicobacter pylori, other Helicobacter species such H.bilis, H.pullorum and others have been isolated from the bile specimens of humans and animals [5-7]. There are very few studies which have investigated the role of Helicobacter species in gall bladder disease from India. We investigated the patients with gall stone disease for evidence of Helicobacter infection by histopathological and serological methods at R.L.Jalappa hospital, Kolar, Karnataka which caters mainly for rural population. 


\section{Materials and Methods}

\section{Subjects}

During the period November 2011 to August 2013, 65 patients with clinical features of biliary calculus disease admitted at R.L.Jalappa hospital, Kolar were included in the study. A diagnosis of calculus cholecystitis was made in these patients based on detailed clinical examination and relevant laboratory and radiological investigations. Patients who were treated for Helicobacter pylori infections in the past 4 weeks and those with clinical features of gastritis were excluded from the study.

\section{Histopathology}

After performing cholecystectomy on the patients selected as above, gall bladder tissues were fixed in 10\% formaldehyde and were subjected to histopathological examination. Sections from the sample were stained by Haematoxylin and Eosin (H \& E) stain and Giemsa stains and examined under microscope for evidence of organisms morphologically resembling Helicobacter.

\section{Serological testing}

A $5 \mathrm{ml}$ blood sample was collected prior to surgery from all the above patients, serum was separated and tested for IgM antibodies to Helicobacter pylori using a commercially available ELISA kit (calbiotech, California. USA). The kit detects Cag-A antibodies against an $128 \mathrm{kd}$ antigen. The results were expressed in antibody units by dividing the optical density value (OD value) of the sample by the cut-off value as per the instructions from the manufacturer. Samples that showed an antibody index of more than 1.1 were considered to be positive for IgM antibodies for Helicobacter.

\section{Results}

Table 1: Demographics and clinical findings in patient with biliary calculus studied.

\begin{tabular}{|c|c|}
\hline Parameter & Number(percentage) \\
\hline Male & $27(41.5 \%)$ \\
\hline Female & $38(58.5 \%)$ \\
\hline Mean age & 41.78 years \\
\hline Pain & $65(100 \%)$ \\
\hline Dyspepsia & $20(30.7 \%)$ \\
\hline Fever & $9(13.8 \%)$ \\
\hline
\end{tabular}

\begin{tabular}{|c|c|}
\hline Sex & Our Study \\
\hline Male & 27 \\
\hline Female & 58 \\
\hline Total & 65 \\
\hline
\end{tabular}

Sixty five patients of calculus cholecystitis were included in the study. Among them, 27(41.5\%) were males and 38 (58.5\%) were females. The mean age of overall study population was $41.78 \pm 8.8$ years. The youngest patient was 14 years old and the oldest patient was 77 years old. Among the patients studied, all patients had pain in the right hypochondrium, in addition, 20 (30.7\%) had dyspepsia and 9 (13.8\%) had fever. There were no patients with jaundice or mass per abdomen (Table 1) (Figure 1). Among the above 65 patients, 42 patients underwent open cholecystectomy and 23 underwent laparoscopic cholecystectomy. 2 patients of laparoscopic cholecystectomy had to be converted to open cholecystectomy due to dense adhesions (Figure 2).

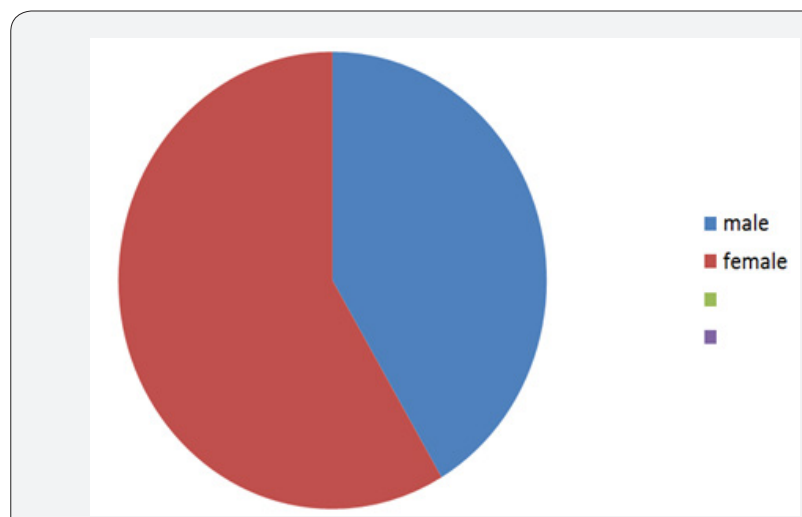

Figure 1: Demographics and clinical findings in patient with biliary calculus studied.

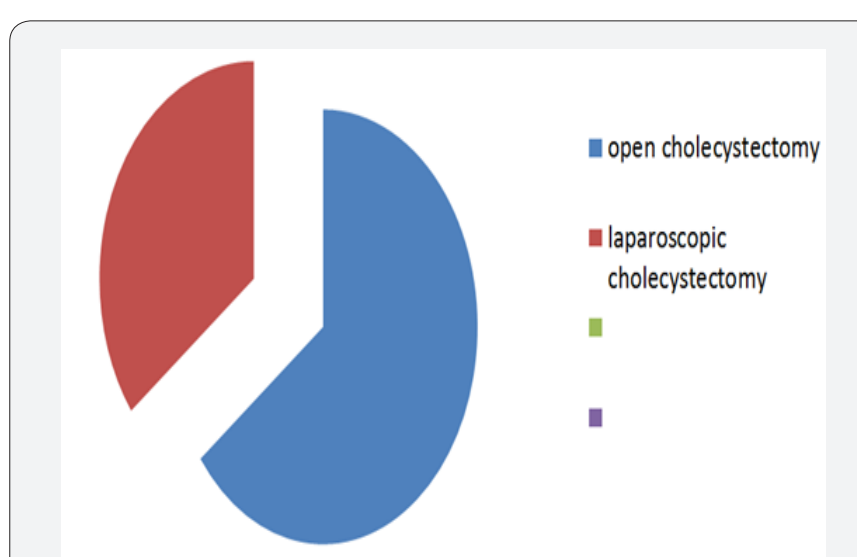

Figure 2: Demographics and clinical findings in patient with biliary calculus studied.

On histopathological examination, 61 (94\%) of the cholecystectomy specimens showed features of calculus cholecystitis and $4(6 \%)$ patients showed features of acalculus chronic cholecystitis. H \& E stained sections showed diffuse infiltration of gall bladder wall by lymphocytes, plasma cells, histiocytes and perimyceal fibrosis. In three cases $\mathrm{H} \& \mathrm{E}$ and Giemsa stain showed organisms morphologically resembling H.pylori (Figures 3 \& 4). The IgM antibodies against Helicobacter Cag-A antigen could be demonstrated in the five (7.6\%) of 65 patients. The antibody index varied between 1.10 to 4.27 . The serological findings along with histopathological observations are presented in Table 2. It was observed that organisms resembling Helicobacter pylori were detected in the gall bladder tissues of all the 3 patients who showed an antibody index of 4.02 and above. 


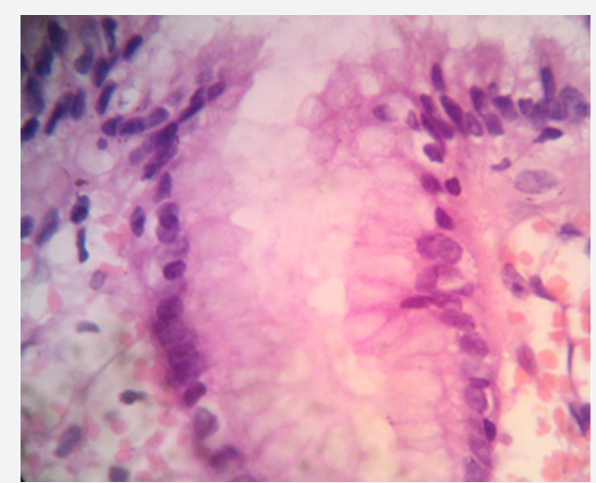

Figure 3: Microphotograph showing an organism morphologically resembling $\mathrm{H}$. pylori in gall bladder tissue with Giemsa stain (arrow).

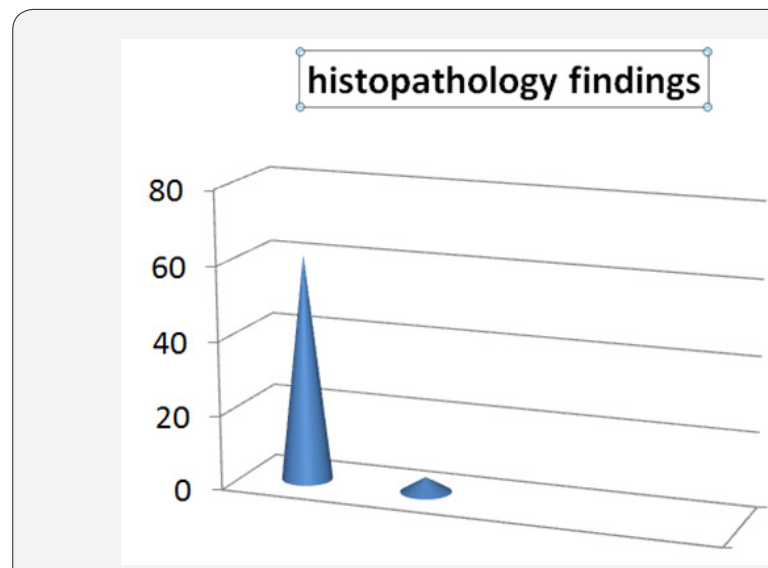

Figure 4: Histopathology Findings.

Table 2: Serological and histopathological evidence of Helicobacter infection in patients with gall stone disease.

\begin{tabular}{|c|c|c|c|c|}
\hline Serial number & Patient number & $\begin{array}{c}\text { Antibody index in IgM } \\
\text { ELISA* }\end{array}$ & $\begin{array}{c}\text { Histopathological } \\
\text { diagnosis }\end{array}$ & $\begin{array}{c}\text { Presence of organism resembling } \\
\text { Helicobacter in gall bladder tissue }\end{array}$ \\
\hline 1 & $\mathrm{M} / 727258$ & 4.27 & calculus cholecystitis & + \\
\hline 2 & $\mathrm{~B} / 778920$ & 4.16 & calculus cholecystitis & + \\
\hline 3 & $\mathrm{M} / 785761$ & 4.02 & calculus cholecystitis & - \\
\hline 4 & $\mathrm{~J} / 735399$ & 1.71 & calculus cholecystitis & - \\
\hline 5 & $\mathrm{D} / 767910$ & 1.10 & calculus cholecystitis & + \\
\hline
\end{tabular}

*The antibody index was calculated by dividing OD value of the sample by the cut off value.

\section{Discussion}

In the study described here, we could detect organisms resembling Helicobacter pylori in gall bladder tissues in 3 (4.6\%) of 65 patients subjected to histopathological examination. We could demonstrate IgM class of antibodies among 5 (7.6\%) of the patients studied. However, those patients with IgM antibody index of 4 and above only (high titres), were associated with histopathological evidence of Helicobacter like organisms in gall bladder tissues. Helicobacter species have been associated with gall stone disease in $1.05 \%$ to $55 \%$ of patients from different parts of the world. Mexico, Greece, Germany and Korea have reported an association of less than 10\% [8-11]. In contrast, Turkey and Pakistan have reported an association of Helicobacter 22\% and $55 \%$ respectively in gall stone disease $[12,13]$.

There are a few studies from India which have explored the possibility of Helicobacter infection in gall bladder disease. The study by Bansal et al. [14] conducted on patients at Delhi showed that Helicobacter DNA could be detected in $32.6 \%$ of 49 gall bladder tissues with gall stone disease. The study at Varanasi by Shukla et al. [5] demonstrated Helicobacter in 28\% of 54 patients with gall stone disease by histopathology, serology and molecular biological methods. Deeba et al. [15] demonstrated IgG class of antibodies against Helicobacter in $80 \%$ of 75 patients with gall stone disease studied at Aligarh. To our knowledge there are no studies examining the role of Helicobacter in gall stone disease, to date, from Southern India.

Our study conducted among a rural population with biliary calculus disease shows that $4.6 \%$ of patients can be associated with Helicobacter infection both by histology and serology. This detection rate is lower compared to that from Northern India. Further investigations are required to confirm the disparity in the association of Helicobacter in gall bladder disease from different parts of the country. Detection of IgM class of antibodies against Helicobacter pylori with higher antibody index in ELISA in the very same patients who had histopathological evidence of presence of organism in the gall bladder tissue suggests that IgM antibodies against Helicobacter pylori can be used as serological a marker to detect the presence of Helicobacter pylori in gall bladder disease.

\section{Similar Studies}

a. Association of the Presence of Helicobacter in Gallbladder Tissue with Cholelithiasis and Cholecystitis. According to this study, results support the hypothesis that Helicobacter is associated with the pathogenesis of human cholelithiasis and cholecystitis but it is less significant and further studies on larger group of population are required to confirm the observations. 
b. Helicobacter pylori DNA in gallbladder tissue of patients with cholelithiasis and cholecystitis. According to this study results, although $\mathrm{H}$. pylori DNA was detected by PCR in gallbladder tissue of patients with cholecystitis, a clinical correlation with biliary disease could not be established but further studies are required to confirm the results.

\section{Conclusion}

In the study reported here from southern India, we found that Helicobacter species in gall bladder tissue could be detected in $3(4.6 \%)$ of 65 patients with Biliary calculus disease. All the 3 patients with histopathological evidence of Helicobacter in gall bladder tissue had higher antibody index(>4.02) for IgM class of antibodies to Helicobacter pylori in ELISA test.

In similarity to the findings of other studies on this subject, we were unable to isolate the bacterium by culture; that may have been due to the fact that the DNA we detected was from nonviable organisms. Conversely, there are different ways to explain our inability to isolate viable bacteria. Firstly, most (85.9\%) patients had received antimicrobial therapy before surgery. In addition, the samples were maintained frozen without any protective solution, which may have compromised bacterial viability. Finally, as discussed above, it is possible that the number of bacterium is very few and that they may have been partially inhibited by adverse conditions in the biliary milieu. In addition, we can speculate that these strains might have had some distinct requirements that are as yet unknown. These facts highlight the need to improve the conditions for the growth of Helicobacter species from the biliary tree to better characterize the microorganism and to allow the development of experimental models for studying the role of Helicobacter in the genesis of biliary diseases.

\section{References}

1. Stinton LM, Myers RP, Shaffer EA (2010) Epidemiology of gall stones. Gastroenterol Clin North Am 39(6): 157-169.

2. Aerts A, Penninekx F (2003) The burden of gallstone disease in Europe. Aliment pharmacolther 18(suppl 3): 49-53.
3. Tandon RK (2000) Prevalence and type of biliary stones in India. World J Gastroenterol 6(suppl 3): 4-5.

4. Zhou D, Zhang Y, Gong W, Mohamed SO, Ogbomo H, Wang X, et al. (2011) Are Helicobacter Species Infection Associated with Human Biliary Lithiasis? A Meta-Analysis. PLoSONE 6(11): e27390.

5. Shukla HS, Tewari M, Mishra RR (2011) Helicobacter pylori and pathogenesis of gallbladder cancer. J Gastroenterol Hepatol 26(2): 260-266.

6. Fox JG, Yan LL, Dewhirst FE, Paster BJ, Shames B, et al. (1995) Helicobacter bilis sp. Nov., a novel Helicobacter species isolated from bile, livers, and intestines of aged, inbred mice. J ClinMicrobiol 33(2): 445-454.

7. Paren Hk, Stenram U, Wadstrom T, Ljungh A (2010) Helicobacter species and common gut bacterial DNA in gallbladder with cholecystitis. World J Gastroentrol 16(38): 4817-4822.

8. Méndez SN, Pichardo R, González J, Sanchez H, Moreno M, et al. (2001) Lack of association between Helicobacter sp colonization and gallstone disease. J Clin Gastroenterol 32(2): 138-141.

9. Griniatsos J, Sougioultz S, Giaslakiotis K, Gazouli M, Prassas E, et al. Does Helicobacter pylori identification in the mucosa of the gall bladder correlate with cholesterol gall stones formation? West indian Med J 58(5): 428-432.

10. Lee JW, Lee DH, Jeong S, Kwon KS, Kim HG, et al. (2010) Identification of Helicobacter pylori in gall stones, bile, and other hepatobiliary tissues of patients with cholecystitis. Gut liver 4(1): 60-67.

11. Rudi J, Rudy A, Maiwald M, Stremmel W (1999) Helicobacter sp. Are not detectable in bile from German patients with biliary disease. Gastroenterology 116(4): 1016-1017.

12. Attaallah W, Yener N, Ugurlu MU, Manukyan M, Asmaz E, Aktan AO (2013) Gallstones and Concomitant Gastric Helicobacter pylori Infection. Gastroenterol Research and Pract 13: 1-4.

13. Abro AH, Haider IZ, Ahmad S (2011) Helicobacter pylori infection in patients with calcular cholecystitis: A hospital based study. J Ayub Med Coll Abbottabad 23(1): 30-33.

14. Bansal VK, Mishra MC, Chaubal G, Gupta DS, Das B, et al. (2012) Helicobacter pylori in gall bladder mucosa in patients with gall bladder disease. Ind J Gastroenterology 31(2): 57-60.

15. Deeba J, Sanjay S, Abida M, Akthar K (2010) Helicobacter pylori in gall bladder disease. Biomedical Research. 21(4): 437-440.

\section{Your next submission with Juniper Publishers} will reach you the below assets

- Quality Editorial service

- Swift Peer Review

- Reprints availability

- E-prints Service

- Manuscript Podcast for convenient understanding

- Global attainment for your research

- Manuscript accessibility in different formats

( Pdf, E-pub, Full Text, Audio)

- Unceasing customer service

Track the below URL for one-step submission https://juniperpublishers.com/online-submission.php 